(1)

Original Article

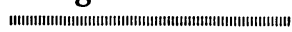

\title{
Quantitative Structure-activity Relationships of the Fungicidal $N$-Benzylacylamides
}

\author{
Osamu Kirino, Chiyozo Takayama and Satoru Inoue \\ Pesticide Research Laboratory, Takarazuka Research Center, \\ Sumitomo Chemical Co., Ltd., Takatsukasa, Takarazuka 665, Japan
}

(Received July 21, 1986)

\begin{abstract}
The fungicidal activity against rice blast, Piricularia oryzae, of $54 \mathrm{~N}$-benzylacylamides having various substituents at the acid and amine moieties was determined in pot tests. The 1-(4-substituted phenyl)ethyl group on the nitrogen atom was necessary for the high activity. The variation in the activity of $N$-(1-phenylethyl)-2-bromo-3,3-dimethylbutanamides having various benzene ring substituents at the 4-position was shown by the Hansch-Fujita method to be correlated with the variation in the hydrophobicity and electronic property of the 4substituents. Both hydrophobicity and steric bulkiness of the substituents in the acyl moiety of $N$-[1-(4-chlorophenyl)ethyl]acylamides were also shown to be important in determining the variation in the activity. The $R$-configuration at both acid and amine moieties of $N$-[1(4-chlorophenyl)ethyl]-2-bromo-3,3-dimethylbutanamide was favorable to the activity.
\end{abstract}

\section{INTRODUCTION}

$N$-Benzylbutanamides with bulky substituents at both acid and amine moieties [e.g., $N$ (1-methyl - 1 - phenylethyl) - 2 - bromo - 3, 3 - dimethylbutanamide, bromobutide] possess potent herbicidal activity against a wide variety of weeds. ${ }^{1,2)}$ In the course of extensive investigations, we found that some kinds of $\mathrm{N}$ benzylacylamides also exhibited fungicidal activity. We synthesized a number of $N$ benzylacylamides with various substituents at the acid and amine moieties and determined their fungicidal activity against rice blast, Piricularia oryzae, in pot tests. $N$-Benzylacylamides such as $N$-[1-(3,4-dichlorophenyl)ethyl]- and $N$-[1-(2,3,4-trichlorophenyl)ethyl]2-bromo-3,3-dimethylbutanamides were found to possess strong fungicidal activity against $P$. oryzae without any phytotoxicity to the rice plants. The residual effect of these compounds was excellent. The structure-activity relationships of fungicidal $N$-benzylacylamides was analyzed by using the Hansch-Fujita method. ${ }^{3)}$ In this paper, we describe the physi- cochemical roles of the substituents on the benzene ring at the 4-position of $N$-(1-phenylethyl)-2-bromo-3, 3-dimethylbutanamides and the substituents in the acid moiety of $N$-[1-(4chlorophenyl)ethyl]acylamides on the activity. The effects of the absolute configurations of the acid and amine moieties of $N$-[1-(4-chlorophenyl) ethyl] - 2 - bromo - 3, 3 - dimethylbutanamide on the activity are also discussed.

\section{MATERIALS AND METHODS}

\section{Compounds}

The $N$-benzylacylamides were synthesized by the reaction of appropriate acyl chlorides with respective benzylamines in the presence of a base. The carboxylic acids were either obtained commercially or prepared according to the methods described in the literatures ${ }^{4-6)}$ and converted into acyl chlorides with thionyl chloride. Optically active 2-bromo-3,3-dimethylbutanoic acids are the same as that reported previously. ${ }^{7)}$ The benzylamines were obtained from corresponding acetophenones by the Leuckart synthesis. ${ }^{8)}$ The $N$-[1-(4-aminophenyl)ethyl] derivative was synthesized by 
catalytic hydrogenation of the corresponding nitro derivative. $R$ - $(+)$-1-(4-Chlorophenyl)ethylamine, ${ }^{9)}[\alpha]_{\mathrm{D}}^{25}+30.8^{\circ} \quad\left(c=1.74, \mathrm{CHCl}_{3}\right)$, and its $S-(-)$ isomer, ${ }^{9)}[\alpha]_{\mathrm{D}}^{25}-29.7^{\circ}(c=1.81$, $\left.\mathrm{CHCl}_{3}\right)$, were obtained from the racemic amine by resolution with (-)- and (+)-1-(4-chlorophenyl)-2-methylbutyric acid. ${ }^{10)}$ The structure of the compounds was confirmed by IR and PMR spectroscopy in addition to the elementary analyses for $\mathrm{C}, \mathrm{H}, \mathrm{N}$, and halogens. All melting points are uncorrected. Optical rotations were measured with a JASCO DIP181 porarimeter. Analysis of optical isomers was performed by gas-liquid chromatography with $N, N^{\prime}$-[2,4-(6-ethoxy-1,3-5-triazin)diyl]bis(1-valyl-1-valyl-1-valine isopropylether) ${ }^{11)}$ as an optically active stationary phase. The following is a typical synthetic procedure.

To a mixture containing $2.4 \mathrm{~g}(0.015 \mathrm{~mol})$ of 1-(4-chlorophenyl)ethylamine, $1.8 \mathrm{~g}(0.018 \mathrm{~mol})$ of triethylamine and $100 \mathrm{ml}$ of benzene, $3.2 \mathrm{~g}$ ( $0.015 \mathrm{~mol})$ of 2-bromo-3,3-dimethylbutanoyl chloride was added under stirring at room temperature. After $6 \mathrm{hr}$, the reaction mixture was washed with water, dilute $\mathrm{HCl}$ and aq. $\mathrm{NaHCO}_{3}$. The organic layer, after dried with anhydrous $\mathrm{Na}_{2} \mathrm{SO}_{4}$, was evaporated to dryness and the residue was recrystallized from ethanol to give $4.1 \mathrm{~g}(82 \%)$ of $N$-[1-(4-chlorophenyl)ethyl]-2-bromo-3,3-dimethylbutanamide, $\mathrm{mp}$ $106-108^{\circ} \mathrm{C}$.

\section{Fungicidal Activity}

Each test compound was formulated as a $20 \%$ emulsifiable concentrate including $16 \%$ Sorpol 1200 (an emulsifier, Toho Chemical Co.), $32 \% N, N$-dimethylformamide and $32 \%$ xylene by weight and the resulting concentrate was diluted with water to desired concentrations. Four stems of the rice plant (cul. var.; Kinki No. 33) were grown in each plastic pot $(120 \mathrm{ml}$ in volume) to the four-leaf stage. The plants were sprayed with the test solution at a rate of $10 \mathrm{ml}$ per pot and after $4 \mathrm{hr}$, they were inoculated by spraying with $10 \mathrm{ml}$ of a spore suspension $\left(1 \times 10^{6}\right.$ cells $\left./ \mathrm{ml}\right)$ of $P$. oryzae. After incubated for 4 days at $26^{\circ} \mathrm{C}$, the plants were assessed for the disease severity against untreated control by counting the number of disease spots on the leaves and the fungicidal activity was expressed as the $\mathrm{pED}_{50}$, negative logarithm of the dose (mol/pot) required for $50 \%$ prevention of the disease development.

\section{RESULTS AND DISCUSSION}

\section{Effect of Amine Moiety Substituents}

Table 1 shows the fungicidal activity of $N$ substituted-2-bromo-3, 3-dimethylbutanamides against $P$. oryzae in the pot test. The activity is greatly influenced by the substituents on the nitrogen atom and the $\alpha$-methyl-4-chlorobenzyl derivative exhibits strong activity. Displacement of the $\alpha$-methyl group of the $\alpha$-methyl-4chlorobenzyl moiety with hydrogen atom or the other alkyl groups greatly decreases the activity. In a previous paper, ${ }^{1)}$ we reported that the $N$-( $\alpha, \alpha$-dimethylbenzyl) group of the same type of amides was favorable to the herbicidal activity. However, the dimethyl substitution at the $\alpha$-position of the 4-chlorobenzyl group results in loss of activity. The critical site for the fungicidal activity corresponding to the amine moiety seems to be different from that for the herbicidal activity. The 2-(4-chlorophenyl)propyl derivative exhibits the activity but the 2-(4-chlorophenyl)ethyl and 1-methyl-2-(4-chlorophenyl)ethyl derivatives do not. These results along with the structure-activity relationship of $\alpha$-substituted-4-chlorobenzyl derivatives may indi-

Table $1 N$-Substituted-2-bromo-3,3-dimethylbutanamides and their fungicidal activity against Piricularia oryzae.

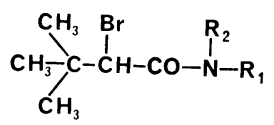

\begin{tabular}{|c|c|c|c|}
\hline $\mathrm{R}_{1}$ & $\mathrm{R}_{2}$ & $\operatorname{mp}\left({ }^{\circ} \mathrm{C}\right)$ & $\mathrm{pED}_{50}$ \\
\hline $\left.\mathrm{C}_{6} \mathrm{H}_{4}-4-\mathrm{Cl}^{\mathrm{a}}\right)$ & $\mathrm{H}$ & $166-167$ & $<4.3$ \\
\hline $\mathrm{CH}_{2}-\mathrm{C}_{6} \mathrm{H}_{4}-4-\mathrm{Cl}$ & $\mathrm{H}$ & $136-137.5$ & $<4.3$ \\
\hline $\mathrm{CH}(\mathrm{Me})-\mathrm{C}_{6} \mathrm{H}_{4}-4-\mathrm{Cl}$ & $\mathrm{H}$ & $106-108$ & 6.52 \\
\hline $\mathrm{CH}(\mathrm{Et})-\mathrm{C}_{6} \mathrm{H}_{4}-4-\mathrm{Cl}$ & $\mathrm{H}$ & $138-139$ & 4.94 \\
\hline $\mathrm{CH}(i-\mathrm{Pr})-\mathrm{C}_{6} \mathrm{H}_{4}-4-\mathrm{Cl}$ & $\mathrm{H}$ & $199-200$ & $<4.3$ \\
\hline $\mathrm{C}(\mathrm{Me})_{2}-\mathrm{C}_{6} \mathrm{H}_{4}-4-\mathrm{Cl}$ & $\mathrm{H}$ & $198-199$ & $<4.3$ \\
\hline $\mathrm{CH}_{2} \mathrm{CH}_{2}-\mathrm{C}_{6} \mathrm{H}_{4}-4-\mathrm{Cl}$ & $\mathrm{H}$ & $115-116$ & $<4.3$ \\
\hline $\mathrm{CH}(\mathrm{Me}) \mathrm{CH}_{2}-\mathrm{C}_{6} \mathrm{H}_{4}-4-\mathrm{Cl}$ & $\mathrm{H}$ & $170-172$ & $<4.3$ \\
\hline $\mathrm{CH}_{2} \mathrm{CH}(\mathrm{Me})-\mathrm{C}_{6} \mathrm{H}_{4}-4-\mathrm{Cl}$ & $\mathrm{H}$ & $111-112$ & 5.24 \\
\hline $\mathrm{CH}(\mathrm{Me})-\mathrm{C}_{6} \mathrm{H}_{4}-4-\mathrm{Cl}$ & $\mathrm{Me}$ & $n_{\mathrm{D}}^{25} 1.5408$ & 4.94 \\
\hline $\mathrm{CH}(\mathrm{Me})-\mathrm{C}_{6} \mathrm{H}_{4}-4-\mathrm{Cl}$ & Et & $69-71$ & $<4.3$ \\
\hline
\end{tabular}

a) 4-Chlorophenyl group. 
Table $2 N$-[1-(Substituted phenyl)ethyl]-2-bromo3,3-dimethylbutanamides and their fungicidal activity against Piricularia oryzae.

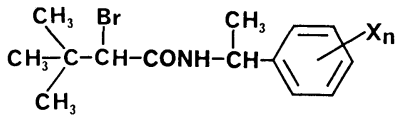

\begin{tabular}{llc}
\hline $\mathrm{X}_{n}$ & $\mathrm{mp}\left({ }^{\circ} \mathrm{C}\right)$ & $\mathrm{pED}_{50}$ \\
\hline $\mathrm{H}$ & $161-163$ & 5.00 \\
$2-\mathrm{Cl}$ & $208-210$ & $<4.3$ \\
$2-\mathrm{Me}$ & $191-192$ & $<4.3$ \\
$2-\mathrm{OMe}$ & $191-195$ & $<4.3$ \\
$3-\mathrm{Cl}$ & $164-168$ & $<4.3$ \\
$3-\mathrm{Me}$ & $194-195.5$ & $<4.3$ \\
$3-\mathrm{OMe}$ & $195-198$ & $<4.3$ \\
$4-\mathrm{Cl}$ & $106-108$ & 6.52 \\
$2,4-\mathrm{Cl}_{2}$ & $227-229.5$ & 6.17 \\
$2,5-\mathrm{Cl}_{2}$ & $181-182$ & 5.39 \\
$3,4-\mathrm{Cl}_{2}$ & $227-229.5$ & 7.15 \\
$2,3,4-\mathrm{Cl}_{3}$ & $176-179$ & 7.60 \\
$\left.1-\mathrm{Np}^{a}\right)$ & $212-213$ & 5.24 \\
$\left.2-\mathrm{Np}^{\mathrm{b}}\right)$ & $165-168$ & 5.84 \\
\hline
\end{tabular}

a) $N$-[1-(1-Naphtyl)ethyl] derivative.

b) $N$-[1-(2-Naphtyl)ethyl] derivative.

cate that the steric relationship between the nitrogen atom of the amide and the 4-chlorophenyl group is important for the activity. Alkylation at the nitrogen atom of the $\alpha$ methyl-4-chlorobenzyl derivative reduces the activity. Therefore, the hydrogen atom attached to the nitrogen atom seems to be essential for the high activity.

As shown in Table 2, the $N$-(1-phenylethyl)2-bromo-3,3-dimethylbutanamide shows some fungicidal activity but its chloro, methyl, and methoxy derivatives at the 2- or 3-position of the benzene ring do not show any activity. On the other hand, the 4-chloro derivative exhibits high activity. In the case of polychlorinated derivatives, the activity of the 3,4dichloro- and 2,3,4-trichloro derivatives is extremely strong. The 4-chloro substitution seems to be favorable for high activity. The $N$-[1-(2-naphtyl)ethyl] derivative shows considerable activity but the 1-naphtyl derivative is less active.

\section{Structure-activity Correlation of Benzene Ring Substituents}

Since the substitution at the 4-position of the benzene ring of $N$-(1-phenylethyl)-2-bromo3,3-dimethylbutanamides seems to be important for high fungicidal activity, a number of derivatives were synthesized and tested for their activity. Then the structure-activity relationship has been quantitatively analyzed by the Hansch-Fujita method $^{3)}$ to delineate the factors governing the activity variation.

As shown in Table 3, the activity varied with the variation of the 4-substituents on the benzene ring. In the preliminary analyses, we found that the hydrophobicity and electronic property of the 4-substituents were important for the variation in the activity. The structure-activity correlation was represented by Eq. (1) with $\pi$ and $\sigma_{\mathrm{I}}$ terms.

$$
\begin{gathered}
\mathrm{pED}_{50}=0.688 \pi+1.898 \sigma_{\mathrm{I}}+5.174 \\
( \pm 0.092)( \pm 0.263)( \pm 0.111) \\
n=10, s=0.187, r=0.970, F=56.37
\end{gathered}
$$

In Eq. (1) $\pi$ is the hydrophobic substituent constant from the benzene system ${ }^{12)}$ and $\sigma_{\mathrm{I}}$ the substituent constant for the localized electronic effect. ${ }^{13)}$ The localized effect is some combination of the inductive (through a bond) and field (through space) effects. ${ }^{13)}$ In this and the following equation, $n$ is the number of data points included in the correlation, $s$ the standard deviation, $r$ the multiple correlation coefficient, and $F$ the $F$-value of the correlation. The figures in parentheses are the 95\% confidence intervals. All the terms are justified above $99.5 \%$ level by the $t$-test unless otherwise noted. The squared correlation coefficient between $\pi$ and $\sigma_{\mathrm{I}}$ is 0.002 .

The positive sign of the $\pi$ term in Eq. (1) means that the greater the hydrophobicity of the 4-substituents, the higher the activity. The 4-substituents may interact hydrophobically with the site critical for the activity. The positive sign of the $\sigma_{\mathrm{I}}$ term indicates that the stronger the electron withdrawal of the 4substituents, the higher the activity. The use of electronic $\sigma^{12)}$ or $\sigma^{\circ 14)}$ constant instead of $\sigma_{\mathrm{I}}$ was fairly significant, i.e., $r=0.833$ for $\sigma$ and $r=0.869$ for $\sigma^{\circ}$. This may be attributed to high collinearity between $\sigma_{\mathrm{I}}$ and $\sigma\left(r^{2}=\right.$ $0.498)$ and between $\sigma_{\mathrm{I}}$ and $\sigma^{\circ}\left(r^{2}=0.642\right)$. Since $\sigma_{\mathrm{I}}$ constant expresses only localized components of the electronic effect and $\sigma$ or $\sigma^{\circ}$ also contains delocalized components, ${ }^{13)}$ 
Table $3 \quad N$-[1-(4-Substituted phenyl)ethyl]-2-bromo-3,3-dimethylbutanamides and their fungicidal activity against Piricularia oryzae.

\begin{tabular}{|c|c|c|c|c|c|}
\hline \multirow{2}{*}{$\mathrm{X}$} & \multirow{2}{*}{$\operatorname{mp}\left({ }^{\circ} \mathrm{C}\right)$} & \multirow{2}{*}{$\pi^{\text {a) }}$} & \multirow{2}{*}{$\left.\sigma_{\text {I }}{ }^{b}\right)$} & \multicolumn{2}{|c|}{$\mathrm{pED}_{50}$} \\
\hline & & & & Obsd. & Calcd. ${ }^{c)}$ \\
\hline $\mathrm{H}$ & $161-163$ & 0.00 & 0.00 & 5.00 & 5.17 \\
\hline $\mathrm{F}$ & $114-115.5$ & 0.14 & 0.54 & 6.40 & 6.30 \\
\hline $\mathrm{Cl}$ & $106-108$ & 0.71 & 0.47 & 6.52 & 6.55 \\
\hline $\mathrm{Br}$ & $140-141$ & 0.86 & 0.47 & 6.81 & 6.66 \\
\hline $\mathrm{CF}_{3}$ & $146-147$ & 0.88 & 0.40 & 6.64 & 6.54 \\
\hline $\mathrm{Me}$ & $127-128$ & 0.56 & -0.01 & 5.60 & 5.54 \\
\hline $\mathrm{OMe}$ & $160-163$ & -0.02 & 0.30 & 5.44 & 5.73 \\
\hline $\mathrm{CN}$ & $126.5-128$ & -0.57 & 0.57 & 5.86 & 5.86 \\
\hline $\mathrm{NH}_{2}$ & $135-137.5$ & -1.23 & 0.17 & 4.89 & 4.65 \\
\hline $\mathrm{NO}_{2}$ & $133-135$ & -0.28 & 0.67 & 6.10 & 6.25 \\
\hline
\end{tabular}

a) Values from the benzene system taken from Ref. 12).

b) Taken from Ref. 13).

c) Calculated by Eq. (1).

Table $4 \quad N$-[1-(4-Chlorophenyl)ethyl]acylamides and their fungicidal activity against Piricularia oryzae.

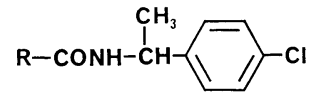

\begin{tabular}{|c|c|c|c|c|c|}
\hline \multirow{2}{*}{$\mathrm{R}$} & \multirow{2}{*}{$\operatorname{mp}\left({ }^{\circ} \mathrm{C}\right)$} & \multirow{2}{*}{$\pi^{\text {a) }}$} & \multirow{2}{*}{$E_{\mathrm{s}}^{\mathrm{c} \mathrm{b})}$} & \multicolumn{2}{|c|}{$\mathrm{pED}_{50}$} \\
\hline & & & & Obsd. & Calcd. ${ }^{c}$ ) \\
\hline$t-\mathrm{Bu}$ & $108-110$ & 1.72 & -2.46 & 4.78 & 5.07 \\
\hline$t-\mathrm{BuCH}_{2}$ & $90-91$ & 2.44 & -2.05 & 5.10 & 5.40 \\
\hline$(\mathrm{Et})_{2} \mathrm{CH}$ & $98-99$ & 2.48 & -2.59 & 5.40 & 5.58 \\
\hline$t-\mathrm{Bu}(\mathrm{Me}) \mathrm{CH}$ & $114-116$ & 2.76 & -3.94 & 6.05 & 6.01 \\
\hline$c$-Hex & $128-129$ & 2.53 & -1.40 & 5.42 & 5.20 \\
\hline$t-\mathrm{Bu}(\mathrm{E} t) \mathrm{CH}$ & $132.5-134$ & 3.30 & -5.67 & 6.13 & 6.27 \\
\hline$(i-\mathrm{Pr})_{2} \mathrm{CH}$ & $145-146.5$ & 3.30 & -5.62 & 6.25 & 6.25 \\
\hline$i-\operatorname{Pr}(\mathrm{E} t)(\mathrm{Me}) \mathrm{C}$ & $112-113$ & 3.21 & -6.13 & 6.45 & 6.49 \\
\hline$c$-Hep & $111-112$ & 3.07 & -1.71 & 5.75 & 5.16 \\
\hline$(i-\mathrm{Pr})_{2}(\mathrm{Me}) \mathrm{C}$ & $90.5-91.5$ & 3.62 & -8.30 & 6.63 & 6.77 \\
\hline $\mathrm{Et}(\mathrm{Br}) \mathrm{CH}$ & $111-114$ & 1.44 & -2.59 & 4.82 & 4.76 \\
\hline$n-\operatorname{Pr}(\mathrm{Br}) \mathrm{CH}$ & $147-148.5$ & 1.98 & -2.61 & 4.99 & 5.36 \\
\hline$i-\operatorname{Pr}(\mathrm{Br}) \mathrm{CH}$ & $109-111.5$ & 1.85 & -3.84 & 6.11 & 5.65 \\
\hline$n-\mathrm{Bu}(\mathrm{Br}) \mathrm{CH}$ & $115-116$ & 2.52 & -2.64 & 5.00 & 5.60 \\
\hline$s-\mathrm{Bu}(\mathrm{Br}) \mathrm{CH}$ & $61-64$ & 2.39 & -3.84 & 5.92 & 5.97 \\
\hline$t-\mathrm{Bu}(\mathrm{Cl}) \mathrm{CH}$ & $99-101$ & 2.09 & -3.94 & 6.38 & 5.87 \\
\hline$t-\mathrm{Bu}(\mathrm{Br}) \mathrm{CH}$ & $106-108$ & 2.26 & -5.67 & 6.52 & 6.52 \\
\hline$t-\mathrm{Bu}(\mathrm{I}) \mathrm{CH}$ & $159-161$ & 2.44 & -5.67 & 6.58 & 6.57 \\
\hline $\mathrm{Et}(\mathrm{Me})_{2} \mathrm{C}(\mathrm{Br}) \mathrm{CH}$ & $99-100.5$ & 2.80 & $-5.67^{d)}$ & 6.76 & 6.55 \\
\hline
\end{tabular}

a) Values from the aliphatic system taken from Ref. 18).

b) Unless otherwise noted, taken from Ref. 21).

c) Calculated by Eq. (2)

d) Taken as that of $t$ - $\mathrm{Bu}(\mathrm{Et}) \mathrm{CH}$. 
high significance of $\sigma_{\text {I }}$ may indicate that the localized electronic effect of the 4-substituents is important for the variation in the activity.

\section{Structure-activity Correlation of Acyl Moiety Substituents}

Table 4 shows the fungicidal activity of $N$ [1-(4-chlorophenyl)ethyl]acylamides in which the activity varies with the variation of the substituents in the acid moiety. In this case, the hydrophobicity and steric bulkiness of the substituents were important for the variation in the activity. The structure-activity correlation was represented by Eq. (2) with $\pi^{2}$, $\pi$, and $E_{\mathrm{s}}^{\mathrm{e}}$.

$$
\begin{gathered}
\mathrm{pED}_{50}=-0.626 \pi^{2}+3.238 \pi-0.323 E_{\mathrm{s}}^{\mathrm{c}} \\
( \pm 0.222)( \pm 1.109)( \pm 0.055) \\
+0.562 \\
( \pm 1.406) \\
n=19, s=0.333, r=0.890, F=19.09
\end{gathered}
$$

In Eq. (2), $\pi$ is the hydrophobic substituent constant from the aliphatic system ${ }^{15)}$ and $E_{\mathrm{s}}^{\mathrm{c}}$ is Hancock's corrected steric substituent constant which is taken as a constant emphasizing the effect of branching besides steric bulk. ${ }^{16)}$ The $\pi^{2}$ and $\pi$ terms are justified between 99 and $97.5 \%$ by the $t$-test. The $\pi$ values were estimated from the observed $\log P$ (1-octanol-water partition coefficient) values for the appropriate compounds according to the additivity principle. ${ }^{15,17)}$ The $E_{\mathrm{s}}^{\mathrm{c}}$ values were calculated from the $E_{\mathrm{s}}$ values ${ }^{18)}$ by the equation, $E_{\mathrm{s}}^{\mathrm{c}}=E_{\mathrm{s}}-0.306(3-n)$ where $n$ is the number of $\alpha$-hydrogen atoms of substituents. ${ }^{19)}$ The $E_{\mathrm{s}}^{\mathrm{c}}$ values of the substituents whose $E_{\mathrm{s}}$ values were unreported were estimated ${ }^{20)}$ by the equation using the $E_{\mathrm{s}}^{\prime}$ values $^{21,22)}$ in place of the $E_{\mathrm{s}}$ values. The squared correlation coefficient between $\pi$ and $E_{\mathrm{s}}^{\mathrm{c}}$ in Eq. (2) is 0.326 .

Equation (2) shows that the fungicidal activity is parabolically related to the hydrophobicity of the substituents, reaching a maximum when $\pi$ is 2.59. The parabolic relationship seems to indicate that the compounds should traverse a number of lipoidal-aqueous interfaces to reach a critical site for the activity. ${ }^{23)} \quad E_{\mathrm{s}}^{\mathrm{c}}$ is related to the bulkiness of substituents: the bulkier the substituent, the more negative the constant. Therefore, the negative sign of the $E_{\mathrm{s}}^{\mathrm{c}}$ term means that the bulkier the substituent, the higher the activity. The degradation of the molecule at the amide moiety may decrease as bulkiness of the substituent increases. Accordingly, the negative sign of the $E_{\mathrm{s}}^{\mathrm{c}}$ term seems to indicate that the chemical stability of the molecule in the plant and/or fungus bodies is important in determining the activity variation. These results are similar to the ones obtained from the correlation analysis of herbicidal $N$-(1-methyl-1phenylethyl)acylamides against Scirpus juncoides $^{17,20)}$ and Cyperus rotundus. ${ }^{24)}$

\section{Relationship between the Absolute Configura- tion and the Activity}

$N$-[1-(4-Chlorophenyl)ethyl]-2-bromo-3, 3-dimethylbutanamide has two assymmetric carbon atoms at the acid and amine moieties. As shown in Table 5 , the fungicidal activity is

\begin{tabular}{|c|c|c|c|c|c|c|}
\hline \multicolumn{4}{|c|}{ Isomer content $(\%)$} & \multirow{2}{*}{$\mathrm{mp}\left({ }^{\circ} \mathrm{C}\right)$} & \multirow{2}{*}[\alpha]{$_{\mathrm{D}}^{25}$ in $\mathrm{CHCl}_{3}$} & \multirow{2}{*}{$\mathrm{pED}_{50}$} \\
\hline$\stackrel{*}{*} \stackrel{* *}{R}$ & $R S$ & $S R$ & $S S$ & & & \\
\hline 99 & 0 & 1 & 0 & $154.5-156$ & $+46.8^{\circ}(c=2.13)$ & 6.80 \\
\hline 0 & 100 & 0 & 0 & $170-172$ & $-18.5^{\circ}(c=1.95)$ & $<4.3$ \\
\hline 0 & 3 & 97 & 0 & $170-172$ & $+18.1^{\circ}(c=0.61)$ & 6.29 \\
\hline 0 & 4 & 0 & 96 & $155-156.5$ & $-44.0^{\circ}(c=0.62)$ & $<4.3$ \\
\hline
\end{tabular}
different for the 4 optical isomers. The com-

Table 5 Optically active $N$-[1-(4-chlorophenyl)ethyl]-2-bromo-3,3-dimethylbutanamides and their fungicidal activity against Piricularia oryzae.

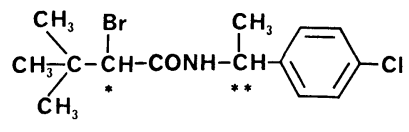


pound with an $R$-configuration at both acid and amine moieties exhibits the highest activity. The compound with an $S$-configuration at the acid moiety and $R$-configuration at the amine moiety shows considerable activity. On the other hand, compounds with an $S$-configuration at the amine moiety are inactive. Therefore, the $R$-configuration at the amine moiety is essential for high activity, whereas the configuration at the acid moiety is less important. We have reported ${ }^{7)}$ that both $R$ configuration at the acid moiety and $S$-configuration at the amine moiety of $N$-(1-phenylethyl)-2-bromo-3, 3-dimethylbutanamide were essential for the herbicidal activity against $S$. juncoides. Such a disagreement suggests that the target site of these amides may differ in configuration between plant and fungi.

\section{ACKNOWLEDGMENTS}

We wish to express our thanks to Dr. Shizuya Tanaka and Dr. Toshiro Kato for their discussions. We thank Dr. Greg Goder of University of California at Berkeley for reviewing the manuscript. We also thank Mr. Kunihiko Furuzawa and Mr. Kiyoto Maeda for their discussion and help.

\section{REFERENCES}

1) O. Kirino, K. Furuzawa, H. Matsumoto, N. Hino \& A. Mine: Agric. Biol. Chem. 45, 2669 (1981)

2) O. Kirino: J. Pesticide Sci. 9, 571 (1984)

3) C. Hansch \& T. Fujita: J. Am. Chem. Soc. 86, 1616 (1964)

4) A.H. Homeyer, F.C. Whitmore \& V.H. Wallingford: J. Am. Chem. Soc. 71, 3929 (1949)

5) K. Bott \& H. Hellmann: Angew. Chem. 78, 932 (1966)

6) J. A. MacPhee \& J.-E. Dubois: J.Chem. Soc., Perkin Trans. I 1977, 694

7) O. Kirino, Y. Suzuki, K. Yanagi, A. Sogabe \& M. Minobe: J. Pesticide Sci. 8, 429 (1983)

8) A. W. Ingersoll, J. H. Brown, C. K. Kim, W. D. Beauchamp \& G. Jennings: J. Am. Chem. Soc. 58, 1808 (1936)

9) H. E. Smith, J. R. Neergaard, T. de Paulis \& F.M. Chen: J. Am. Chem. Soc. 105, 1578 (1983)

10) M. Miyakado, N. Ohno, Y. Okuno, M. Hirano, K. Fujimoto \& H. Yoshioka: Agric. Biol. Chem. 39, 267 (1975)

11) N. Ooi, M. Horiba, H. Kitahara \& H. Shimada: J. Chromatogr. 202, 302 (1980)

12) C. Hansch, A. Leo, S. H. Unger, K.-H. Kim, D.
Nikaitani \& E. J. Lien: J. Med. Chem. 16, 1207 (1973)

13) M. Charton: "Progress in Physical Organic Chemistry," $\epsilon$ d. by R. W. Taft, Vol. 13, John Wiley \& Sons, New York, p. 119, 1981

14) O. Exner: "Advances in Linear Free Energy Relationships," ed. by N. B. Chapman \& J. Shorter, Plenum, London, 1972

15) C. Hansch \& A. Leo: "Substituent Constants for Correlation Analysis in Chemistry and Biology," John Wiley \& Sons, NewYork, 1979

16) T. Fujita: Pure Appl. Chem. 50, 987 (1978)

17) O. Kirino, K. Furuzawa, C. Takayama \& T. Mizutani: J. Pesticide Sci. 9, 345 (1983)

18) R. W. Taft, Jr.: "Steric Effects in Organic Chemistry," ed. by M. S. Newman, John Wiley \& Sons, New York, p. 556, 1956

19) C. K. Hancock, E. A. Meyers \& B. J. Yager: J. Am. Chem. Soc. 83, 4211 (1961)

20) O. Kirino, K. Furuzawa, C. Takayama, H. Matsumoto \& A. Mine: J. Pesticide Sci. 8, 301 (1983)

21) A. Panaye, J. A. MacPhee \& D. Dubois: Tetrahedron 36, 759 (1980)

22) J. A. MacPhee, A. Panaye \& D. Dubois: Tetrahedron 34, 3553 (1978)

23) J. T. Pennistone, L. Beckett, D. L. Bentley \& C. Hansch: Mol. Pharmacol. 5, 333 (1969)

24) O. Kirino, S. Hashimoto, K. Furuzawa, C. Takayama \& A. Mine: J. Pesticide Sci. 8, 315 (1983)

\section{要 約}

\section{殺菌活性を有する $N$-benzylacylamides $の$ 定量 的構造活性相関}

桐野 修, 高山千代蔵, 井上 悟

酸部位㧍よびフミン部位に種々の置換基を有する， 54 個の $N$-benzylacylamides の稲熱病, Piricularia oryzae に対する殺菌活性を,ポット試験で測定した。その結果, 高活性発現には窒素原子に結合した1-(4-置換フェニル)エチル基が必要であることが示された．Hansch-藤田法 による定量的構造活性相関解析から, ベンゼン環の 4 位 の置換基が種々変化した $N$-(1-phenylethyl)-2-bromo-3,3dimethylbutanamides の活性変化は, 4 位置換基の疎水 性および電子的性質と密接な関係のあることがわかっ た. また, $N$-[1-(4-chlorophenyl)ethyl]acylamides の活性 変化には，アシル残基の疎水性と立体的かさ高さが重要 であることが明らかとなった。 N-[1-(4-chlorophenyl)ethyl]-2-bromo-3,3-dimethylbutanamide $の 4$ 種の光学活 性体のなかでは, 酸部位・アミン部位ともに $R$ 配置の ものが高活性を示すととがわかった。 